\title{
NUTRIENTS IN SOIL LAYERS UNDER NO-TILLAGE AFTER SUCCESSIVE PIG SLURRY APPLICATIONS ${ }^{(1)}$
}

\author{
Cledimar Rogério Lourenzi ${ }^{(2)}$, Carlos Alberto Ceretta ${ }^{(3)}$, Leandro Souza da Silva ${ }^{(3)}$, \\ Eduardo Girotto $^{(4)}$, Felipe Lorensini ${ }^{(5)}$, Tadeu Luis Tiecher $^{(6)}$, Lessandro De Conti ${ }^{(6)}$, \\ Gustavo Trentin $^{(7)}$ \& Gustavo Brunetto ${ }^{(8)}$
}

\begin{abstract}
SUMMARY
Successive applications of pig slurry to soils under no-tillage can increase the nutrient levels in the uppermost soil layers and part of the nutrients may be transferred to deeper layers. The objective was to evaluate the distribution of nutrients in the profile of a soil after 19 pig slurry applications under no-tillage for 93 months. The experiment was conducted from May 2000 to January 2008 in an experimental area of the Federal University of Santa Maria, southern Brazil, on a Typic Hapludalf. The treatments consisted of pig slurry applications $(0,20,40$ and $80 \mathrm{~m}^{3} \mathrm{ha}^{-1}$ ) and at the end of the experiment, soil samples were collected (layers 0 2, 2-4, 4-6, 6-8, 8-10, 10-12, 12-14, 14-16, 16-18, 18-20, 20-25, 25-30, 30-35, 35-40, 40-50 and 50-60 cm). The levels of mineral $N$, available $P$ and $K$ and total $N, P$ and $K$ were evaluated. The 19 pig slurry applications in 93 months promoted migration of total $N$ and $P$ down to $30 \mathrm{~cm}$ and available $P$ and $K$ to the deepest layer analyzed. At the end of the experiment, no increase was observed in mineral $N$ content in the deeper
\end{abstract}

(1) Part of the work developed by the first author for a master's degree in Soil Science (PPGCS) at the Universidade Federal de Santa Maria - UFSM. Received for publication on January 24, 2012 and approved on November $1^{\text {th }}, 2012$.

(2) Agronomist, Master in Soil Science, Doctoral student of PPGCS at UFSM, Rural Sciences Center - CCR. Caixa Postal 221. CEP 97105-900 Santa Maria (RS), Brazil. Supported by a Doctoral scholarship of CAPES. E-mail: lourenzicr@gmail.com

(3) Agronomist, Doctor in Soil Science, Professor of the Soil Department of UFSM, CCR. Caixa Postal 221. CEP 97105-900 Santa Maria (RS), Brazil. Supported by a research award of CNPq. E-mail: carlosceretta@gmail.com; leandro@smail.ufsm.br

(4) Agronomist, Doctor in Soil Science, Professor of Federal Institute of Education, Science and Technology of Rio Grande do Sul, Nelsi Ribas Fritsch Street, 1111. CEP 98200-000 Ibirubá (RS), Brazil. E-mail: eduardogirotto@hotmail.com

(5) Agronomist, Master in Soil Science, Doctoral student in the PPGCS. Supported by a Doctoral scholarship by CNPq. E-mail: felipe.lorensini@hotmail.com

(6) Agronomist, Master's degree from the PPGCS. Supported by a Master's scholarship of CAPES. E-mail: tadeu.t@hotmail.com; lessandrodeconti@gmail.com

(7) Agronomist, Doctor in Agronomy, Research at the Brazilian Agricultural Research Corporation South, Bagé (RS). E-mail: gustavotrentin@yahoo.com.br

(8) Agronomist, Doctor in Soil Science, Professor of the Soil Department at the Federal University of Santa Catarina (UFSC), Center of Agricultural Science, Rural Engineering Department. Admar Gonzaga highway, 1346. CEP 88034-000 Florianópolis (SC), Brazil. E-mail: brunetto.gustavo@gmail.com 
layers, but increased levels of available $P$ and $K$, showing a transfer of $N$, $P$ and $K$ to layers below the sampled. This evidences undesirable environmental and economic consequences of the use of pig slurry and reinforces the need for a more rational use, i.e., applications of lower manure doses, combined with mineral fertilizers.

\author{
Index terms: organic fertilization, nutrient migration, environmental \\ contamination.
}

\title{
RESUMO: NUTRIENTES EM CAMADAS DE SOLO SUBMETIDO A SUCESSIVAS APLICAÇÕES DE DEJETO LÍQUIDO DE SUÍNOS E SOB PLANTIO DIRETO
}

\begin{abstract}
Aplicações sucessivas de dejeto de suínos em solos sob plantio direto podem aumentar os teores de nutrientes em suas camadas superficiais, bem como parte desses podem ser transferidos para as mais profundas. O objetivo deste trabalho foi avaliar a distribuição de nutrientes no perfil de um solo com 19 aplicações de dejeto líquido de suínos em sistema de plantio direto, durante 93 meses. $O$ experimento foi conduzido em área experimental da Universidade Federal de Santa Maria, no período de maio de 2000 a janeiro 2008, em um Argissolo Vermelho distrófico arênico. Os tratamentos consistiram da aplicação de 0, 20, 40 e $80 \mathrm{~m}^{3} \mathrm{ha}^{-1}$ de dejeto líquido de suínos e, no final do experimento, amostras de solo foram coletadas nas camadas 0-2, 2-4, 4-6, 6-8, 8-10, 10-12, 12-14, 14-16, 16-18, 18-20, 20-25, 25-30, 30-35, 35-40, 40-50 e 50-60 cm. Foram determinados os teores de $N$ mineral, $P$ e $K$ disponíveis e os teores totais de N, P e K. As 19 aplicações de dejeto de suínos por 93 meses promoveram o deslocamento de $N$ e $P$ total até $30 \mathrm{~cm}$ e $P$ e $K$ disponíveis até a camada mais profunda analisada. Essas 19 aplicações não promoveram incremento no teor de $N$ mineral do solo, mas aumentaram os níveis de $P$ e $K$ disponíveis, demonstrando a transferência de $P$ e $K$ para as camadas mais profundas do que as do limite da amostra. Isso evidencia indesejáveis consequências ambientais e econômicas para o uso de dejeto de suínos e reforça a necessidade de racionalidade na sua utilização, o que envolve o uso de doses menores de dejeto combinado com fertilizantes minerais.
\end{abstract}

Termos de indexação: adubação orgânica, migração de nutrientes, contaminação ambiental.

\section{INTRODUCTION}

Swine production in Brazil, as in the traditional swine-producing countries of the world, is an important income source of small farms, especially in the south of the country. This region accounts for $54.2 \%$ of the country's swine herd, with approximately 39.4 million heads (ABIPECS, 2009). The high swine population, mainly raised in feedlots, has increased the pig slurry production. (Ceretta et al., 2010), which is used as organic nutrient source in areas with annual crops and/or pastures. However, the amounts of manure applied are generally high and frequent and promote an accumulation of certain nutrients over the years, surpassing the soil adsorption capacity and crop requirements (McDowell et al., 2001; Basso et al., 2005; Berwanger et al., 2008; Scherer et al., 2010). Furthermore, the increased nutrient concentration in the soil may enhance element transfer by runoff and percolation, such as nitrogen $(\mathrm{N})$ and phosphorus $(\mathrm{P})$, contaminating surface water and groundwater supplies (Daudén et al., 2004; Bergström \& Kirchmann, 2006; Ceretta et al., 2010).
Nitrogen is one of the nutrients in pig slurry with highest concentrations, of which approximately $50 \%$ is in ammoniacal forms $\left(\mathrm{N}_{-} \mathrm{NH}_{4}{ }^{+}\right.$and $\left.\mathrm{N}-\mathrm{NH}_{3}{ }^{-}\right)$ (Joshi et al., 1994; Aita et al., 2006). After manure application, nitrification occurs by nitrifying bacteria that oxidize ammoniacal $\mathrm{N}$ to nitrate $\left(\mathrm{N}-\mathrm{NO}_{3}{ }^{-}\right)$. Nitrification rates may vary from 0.98 to $1.53 \mathrm{~kg}$ ha $^{-1}$ day $^{-1}$ in manured soils, as observed by Aita et al. (2006) in an assessment carried out four days after pig slurry applications of 40 and $80 \mathrm{~m}^{3} \mathrm{ha}^{-1}$, respectively, and all ammoniacal $\mathrm{N}$ present in manure can be nitrified within 10 days after manure application (Chantigny et al., 2001). This rapid transformation of ammoniacal $\mathrm{N}$ to $\mathrm{N}-\mathrm{NO}_{3}{ }_{3}^{-}$ significantly increases the concentration of $\mathrm{N}_{-} \mathrm{NO}_{3}-$ in soil (Loria \& Sawyer, 2005). However,

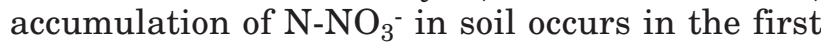
days after pig slurry application (Chantigny et al., 2004; Assmann et al., 2007; Adeli et al., 2008) and decreases over time due to its transfer by runoff (Smith et al., 2001a; Ceretta et al., 2010) and, mainly, percolation (Daudén et al., 2004; Basso et al., 2005; Bergström \& Kirchmann, 2006), as it forms an outer- 
sphere complex with low binding energy with surface functional groups of reactive soil particles.

Similarly to N, P is found in great quantities in pig slurry, of which more than $60 \%$ is in inorganic forms (Cassol et al., 2001). In soil, inorganic P resulting from applications or organic $\mathrm{P}$ mineralization is absorbed predominantly by the mechanism of ligand exchange. This occurs primarily in adsorption sites with higher avidity for phosphate ion forming high energy bonds and resulting in low nutrient availability in soil solution. However, the addition of high amounts of $\mathrm{P}$ in the manure causes a reduction in the adsorption capacity of soil adsorption sites (Siddique \& Robinson, 2003; Adeli et al., 2008). As a result, phosphate ions are adsorbed with lower binding energy, increasing their concentration in soil solution (McDowell et al., 2001) and their transfer by runoff (Smith et al., 2001b; Daverede et al., 2004; Ceretta et al., 2010) and percolation (Basso et al., 2005; Vadas, 2006) possibly causing eutrophication of water sources.

Potassium (K) in pig slurry is found in its entirety in mineral form and is $100 \%$ available at the time of slurry application (Ceretta et al., 2003). In soils treated with pig slurry, Adeli et al. (2008) found K accumulation (Mehlich-3) to a depth of $30 \mathrm{~cm}$. However, $\mathrm{K}$ applied to soil forms weak ionic bonds with the surface functional groups (Kaminski et al., 2007), resulting in low accumulation levels, as observed by Scherer et al. (2007) in a Typic Hapludalf treated with pig slurry. These authors found no K accumulation after four annual manure applications of 40 and $115 \mathrm{~m}^{3} \mathrm{ha}^{-1}$. In addition, $\mathrm{K}$ is the nutrient absorbed in highest quantities by most crops and is exported in large amounts in grains or dry matter (Ceretta et al., 2003).

The objective was to evaluate the nutrient distribution in the profile of a soil under no-tillage after 19 pig slurry applications in 93 months, and to draw conclusions about the potential for $\mathrm{N}$ and $\mathrm{P}$ contamination in the environment.

\section{MATERIALS AND METHODS}

This study was conducted in the experimental area of the Department of Agricultural Engineering of the Federal University of Santa Maria (UFSM), in the State of Rio Grande do Sul, southern Brazil (29 43' 12 " S, $\left.53^{\circ} 43^{\circ} 4^{\prime \prime} \mathrm{W}\right)$. The soil is classified as Typic Hapludalf Soil (Soil Survey Staff, 1999) with sandy loam texture in the $0-10 \mathrm{~cm}$ layer $\left(530 \mathrm{~g} \mathrm{~kg}^{-1}\right.$ sand; $300 \mathrm{~g} \mathrm{~kg}^{-1}$ silt and $170 \mathrm{~g} \mathrm{~kg}^{-1}$ clay). The climate is humid subtropical, classified as Cfa, according to the Köppen classification. The average annual temperature, rainfall and relative humidity are $19.3^{\circ} \mathrm{C}, 1,561 \mathrm{~mm}$ and $82 \%$, respectively.

The experiment was implemented in May 2000 in an area under no-tillage for eight years, on a $4 \%$ slope. Soil was sampled from the $0-10 \mathrm{~cm}$ layer at the beginning of the experiment (see properties in table 1). The experiment was arranged in a randomized block design with three replications and of $4 \times 3 \mathrm{~m}$ $\left(12 \mathrm{~m}^{2}\right)$ plots. Treatments consisted of pig slurry rates $\left(0,20,40\right.$ and $\left.80 \mathrm{~m}^{3} \mathrm{ha}^{-1}\right)$, which were broadcast by hand before the implementation of each succession crop. Manure was the only nutrient source applied to crops. The experiment was initiated in January 2008 , including a total of 19 applications in a period of 93 months. The characteristics of the manure applied before the implementation of each crop and the nutrient quantities supplied via pig slurry are shown in table 2. The swine manure used in the experiment was taken from outdoor compost piles from farms of the Central Depression region of the State of Rio Grande do Sul.

The following succession crops were planted in the experiment: black oat (Avena strigosa Schreb), maize (Zea mays L.) and radish (Raphanus sativus L.) in the growing seasons 2000/01 and 2001/02 (Ceretta et al., 2005); black oat, millet (Pennisetum americanum L.) and black bean (Phaseolus vulgaris L.) in 2002/ 03, black oat+vetch (Vicia sativa L.) and maize in 2003/04 and 2004/05; black oat, black bean and sunnhemp (Crotalaria juncea L.) in 2005/06, black oat, maize and black oat in 2006/07.

In January 2008, 93 months after implantation of the experiment, soil samples were collected in the three replications per treatment. A $60 \mathrm{~cm}$ trench was dug with a shovel for soil collection. Subsequently, slices of soil were cut from the trench wall and separated in layers (0-2, 2-4, 4-6, 6-8, 8-10, 10-12, 12-14, 14-16, 16$18,18-20,20-25,25-30,30-35,35-40,40-50$ and 50-60 $\mathrm{cm})$. The soil was air-dried, manually ground with a clod breaker, sieved through $2 \mathrm{~mm}$ mesh and stored. In addition, soil from the layers $0-2,2-4,4-6,6-8,8$ $10,10-12,12-14,14-16,16-18$ and $18-20 \mathrm{~cm}$ was sampled and stored in a freezer at $-5{ }^{\circ} \mathrm{C}$.

Table 1. Soil physical and chemical properties before the experiment

\begin{tabular}{lc}
\hline Property & Value \\
\hline Clay $\left(\mathrm{g} \mathrm{kg}^{-1}\right)$ & 170 \\
Silt $\left(\mathrm{g} \mathrm{kg}^{-1}\right)$ & 300 \\
Sand $\left(\mathrm{g} \mathrm{kg}^{-1}\right)$ & 530 \\
$\mathrm{pH}\left(\mathrm{H}_{2} \mathrm{O}\right)$ & 4.7 \\
$\mathrm{SMP}$ & 5.5 \\
Organic matter $\left(\mathrm{g} \mathrm{kg}^{-1}\right)$ & 16 \\
$\mathrm{P}\left(\mathrm{mg} \mathrm{kg}^{-1}\right)$ & 15 \\
$\mathrm{~K}\left(\mathrm{mg} \mathrm{kg}^{-1}\right)$ & 96 \\
$\mathrm{Ca}\left(\mathrm{cmol}_{\mathrm{c}} \mathrm{dm}^{-3}\right)$ & 2.7 \\
$\mathrm{Mg}\left(\mathrm{cmol}_{\mathrm{c}} \mathrm{dm}^{-3}\right)$ & 1.1 \\
$\mathrm{Base} \mathrm{saturation}(\%)$ & 42 \\
$\mathrm{Al} \mathrm{saturation}(\%)$ & 17 \\
$\mathrm{CTC} \mathrm{pH}_{7,0}\left(\mathrm{cmol}_{\mathrm{c}} \mathrm{dm}^{-3}\right)$ & 9.6 \\
\hline
\end{tabular}


Table 2. Characteristics of pig slurry and nutrient amounts applied before the implementation of each crop in the experimental period of 93 months

Pig slurry

characteristic

Nutrient applied before each culture

First agricultural year (2000/2001)

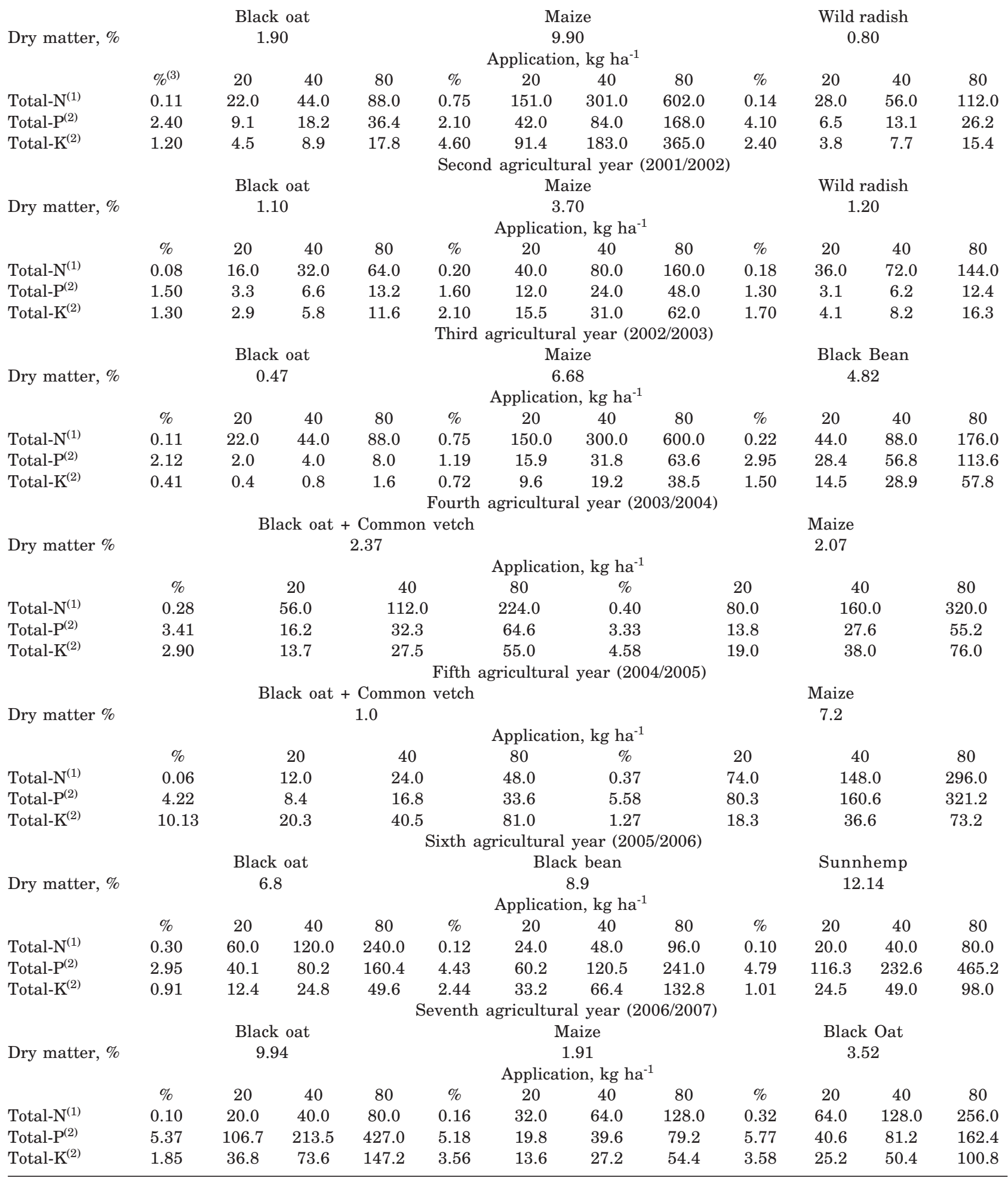

(1) Analyses and calculations on a humid weight basis; ${ }^{(2)}$ Analyses and calculations on a dry weight basis; ${ }^{(3)}$ Percentage of nutrient in pig slurry. 
To determine the concentration of total nitrogen $(\mathrm{N}), 0.5 \mathrm{~g}$ of dry soil was filled in $50 \mathrm{~mL}$ digestion tubes with $2 \mathrm{~mL}$ of concentrated sulfuric acid, $1 \mathrm{~mL}$ of $30 \%$ hydrogen peroxide and $0.7 \mathrm{~g}$ of a digestion mixture $\left(\mathrm{Na}_{2} \mathrm{SO}_{4}+\mathrm{CuSO}_{4} \cdot 5 \mathrm{H}_{2} \mathrm{O}\right)$, according to the method proposed by Tedesco et al. (1995). Subsequently, $20 \mathrm{~mL}$ of sample was distilled in a Kjeldahl distiller with $10 \mathrm{~mL}$ of $10 \mathrm{~mol} \mathrm{~L}^{-1} \mathrm{NaOH}$. The distilled fraction was collected in boric acid and titrated with $0.025 \mathrm{~mol} \mathrm{~L}^{-1} \mathrm{H}_{2} \mathrm{SO}_{4}$.

Samples collected down to a depth of $20 \mathrm{~cm}$ and frozen were used to determine the mineral $\mathrm{N}$ levels. For the extraction of mineral $\mathrm{N}, 5 \mathrm{~g}$ of soil and $50 \mathrm{~mL}$ of $1 \mathrm{~mol} \mathrm{~L}^{-1} \mathrm{KCl}$ were filled in $100 \mathrm{~mL}$ snap-cap bottles. The samples were shaken intermittently for $30 \mathrm{~min}$ and left to stand for 30 min (Tedesco et al., 1995). Subsequently, a $20 \mathrm{~mL}$ sample was distilled in a Kjeldahl distiller with $0.2 \mathrm{~g} \mathrm{MgO}$ to determine the $\mathrm{N}$ $\mathrm{NH}_{4}{ }^{+}$levels and with $0.2 \mathrm{~g}$ of Devarda's alloy to determine the levels of $\mathrm{N}^{-\mathrm{NO}_{3}}{ }^{-}$. The distilled fraction was collected in boric acid and titrated with 0.0025 $\mathrm{mol} \mathrm{L}^{-1} \mathrm{H}_{2} \mathrm{SO}_{4}$.

To determine levels of total $\mathrm{P}$ and $\mathrm{K}, 5 \mathrm{~g}$ of dry soil, $5 \mathrm{~mL}$ of hydrogen peroxide, $10 \mathrm{~mL}$ hydrofluoric acid, $2 \mathrm{~mL}$ of perchloric acid and $5 \mathrm{~mL}$ of hydrochloric acid were filled in a Teflon becker (Helmke \& Sparks, 1996). After digestion, $3 \mathrm{~mL}$ of each sample was pipetted into $50 \mathrm{~mL}$ plastic cups and a drop of $0.25 \%$ $p$-nitrophenol a drop of $10 \mathrm{~mol} \mathrm{~L}^{-1} \mathrm{NaOH}$ and $0.5 \mathrm{~mL}$ of ascorbic acid solution were added, according to the method proposed by Murphy \& Riley (1962). Samples were subjected to a UV-visible spectrophotometer. The levels of total $\mathrm{K}$ were determined by flame spectrophotometry (B262 Micronal).

Available $\mathrm{P}$ and $\mathrm{K}$ were extracted by filling $5 \mathrm{~g}$ of dry soil and $50 \mathrm{~mL}$ of Mehlich-1 in snap-cap bottles. Samples were shaken for $10 \mathrm{~min}$ and left to stand for $12 \mathrm{~h}$. Then the available P levels were determined according to the above method. The levels of available K were determined by flame spectrophotometry (B262 Micronal).

The variation factors amounts of manure applied and soil layers were evaluated. Variance analysis was used to verify interaction between factors at $p<0.05$. For the qualitative factor, the soil layers at the same dose differed significantly, when the average values were compared by the Scott-Knott test $(\alpha<0.05)$. For the quantitative factor, the rates in the same soil layer differed significantly. Linear regression equations verified by the T-test $(p<0.05)$ were fitted and the coefficient of determination of the equation was determined.

\section{RESULTS AND DISCUSSION}

Successive pig slurry applications for 93 months promoted increasing levels of total $\mathrm{N}$ down to a depth of $30 \mathrm{~cm}$ at manure rates of $80 \mathrm{~m}^{3} \mathrm{ha}^{-1}$ and down to
$25 \mathrm{~cm}$ at rates of 20 and $40 \mathrm{~m}^{3} \mathrm{ha}^{-1}$ (Table 3). Considering only the 0-2 cm layer, the increase in total $\mathrm{N}$ was 14,30 and $88 \%$ for 20,40 and $80 \mathrm{~m}^{3} \mathrm{ha}^{-1}$ of pig slurry, respectively. However, the increase in the top soil layers may be even higher, reaching $153 \%$, as observed in the USA by Adeli et al. (2008) after pig slurry applications to a pasture area for 15 years. These results can be explained by higher dry matter production of crops in the treatments with manure applications (Ceretta et al., 2005), as well as the use of no-tillage during the experiment, which provided an increase in levels of soil organic matter, as observed by Lourenzi et al. (2011). This is because total $\mathrm{N}$ is closely related with the levels of soil organic carbon (SOC), as stated by Baldi et al. (2010). These authors, studying different nutrient sources for eight years, observed that increased SOC promoted an increase in total N, with a correlation of $94 \%$.

Despite the $\mathrm{N}$ in manure applications, the increase of soil total N usually occurs gradually and slowly as the SOC content increases (Wienhold, 2005). As a result, many fertilizer recommendation systems rely on the SOC content to determine the quantity of $\mathrm{N}$ to be applied to crops, as in the case of the fertilizer recommendation system proposed by the Commission in Chemistry and Soil Fertility of the States of Rio Grande do Sul and Santa Catarina (CQFSRS/SC, 2004), in southern Brazil. Thus, these results indicate that when total $\mathrm{N}$ in soil treated with pig slurry increases, the amount of $\mathrm{N}$ added to crops in other nutrient sources or even the manure rates may be reduced.

After 19 applications of $0,20,40$ and $80 \mathrm{~m}^{3} \mathrm{ha}^{-1}$ of pig slurry for 93 months, there was no increase in soil mineral $\mathrm{N}$, despite quantities of $951,1,902$ and $3,804 \mathrm{~kg} \mathrm{ha}^{-1}$ of $\mathrm{N}$ added to soil at rates of 20,40 and $80 \mathrm{~m}^{3} \mathrm{ha}^{-1}$, respectively. This shows that there was a transfer of mineral $\mathrm{N}$ to layers below $60 \mathrm{~cm}$ when using pig slurry. This was confirmed by Aita et al. (2006) under conditions similar to the ones in this study. In addition, transfer by runoff occurred as well as reported by Ceretta et al. (2010) and Smith et al (2001a). Furthermore, mineral $\mathrm{N}$ may be involved in transfer by ammonia volatilization, mainly from soils under no-tillage, once manure is applied onto crop residues without soil incorporation (Basso et al., 2005) and the transferred quantities may reach $32 \%$ of the total $\mathrm{N}$ applied via manure (Mkhabela et al., 2008).

Some studies indicate accumulation of mineral N in soils after a sequence of pig slurry application, as those conducted by Chantigny et al. (2004), Assmann et al. (2007) and Adeli et al. (2008), though these results can be explained by the soil sampling time. While in these studies the soil was sampled no later than five months after manure application, the soil in our study was sampled 10 months after the last pig slurry application. This also helps to explain the non-increase in levels of mineral $\mathrm{N}$ under the latter experimental conditions.

Total $P$ content increased to a depth of $30 \mathrm{~cm}$ after 19 pig slurry applications, particularly in the $0-2 \mathrm{~cm}$ 
Table 3. Amounts of total and mineral nitrogen (N) in layers of Typic Hapludalf after 19 pig slurry applications

\begin{tabular}{|c|c|c|c|c|c|c|}
\hline \multirow{2}{*}{ Layer } & \multicolumn{4}{|c|}{ Pig slurry rate $\left(\mathrm{m}^{3} \mathrm{ha}^{-1}\right)$} & \multirow{2}{*}{ Equation } & \multirow{2}{*}{$\mathbf{R}^{2}$} \\
\hline & $\mathbf{0}$ & 20 & 40 & 80 & & \\
\hline $\mathrm{cm}$ & \multicolumn{4}{|c|}{ Total N, mg kg ${ }^{-1}$} & & \\
\hline $0-2$ & $1,738 \mathrm{a}^{(1)}$ & $1,983 \mathrm{a}$ & $2,250 \mathrm{a}$ & $3,275 \mathrm{a}$ & $\hat{y}=1,630.7+19.44 x$ & $0.97^{*}$ \\
\hline $2-4$ & $1,403 \mathrm{~b}$ & $1,648 \mathrm{~b}$ & $1,849 \mathrm{~b}$ & $2,606 \mathrm{~b}$ & $\hat{y}=1,350.0+15.05 x$ & $0.98^{*}$ \\
\hline $4-6$ & $1,114 \mathrm{c}$ & $1,448 \mathrm{c}$ & $1,537 \mathrm{c}$ & $1,648 \mathrm{c}$ & $\hat{y}=1,225.2+6.05 x$ & $0.80^{*}$ \\
\hline $6-8$ & $958 \mathrm{~d}$ & $1,092 \mathrm{~d}$ & $1,426 \mathrm{c}$ & $1,403 \mathrm{~d}$ & $\hat{y}=1,015.8+5.82 x$ & $0.74^{*}$ \\
\hline $8-10$ & 824 e & $1,092 \mathrm{~d}$ & $1,158 \mathrm{~d}$ & $1,381 \mathrm{~d}$ & $\hat{y}=886.6+6.49 x$ & $0.93^{*}$ \\
\hline $10-12$ & $718 \mathrm{f}$ & $958 \mathrm{~d}$ & $1,114 \mathrm{~d}$ & $1,203 \mathrm{~d}$ & $\hat{y}=796.3+5.77 x$ & $0.86^{*}$ \\
\hline $12-14$ & $757 \mathrm{e}$ & 869 e & $936 \mathrm{e}$ & $1,136 \mathrm{e}$ & $\hat{y}=761.9+4.65 x$ & $0.99^{*}$ \\
\hline $14-16$ & $802 \mathrm{e}$ & $824 \mathrm{e}$ & $902 \mathrm{e}$ & $1,136 \mathrm{e}$ & $\hat{y}=764.0+4.34 x$ & $0.94^{*}$ \\
\hline $16-18$ & $702 \mathrm{f}$ & $802 \mathrm{e}$ & $824 \mathrm{e}$ & $1,025 \mathrm{e}$ & $\hat{y}=701.8+3.90 x$ & $0.97^{*}$ \\
\hline $18-20$ & $601 \mathrm{f}$ & 802 e & $802 \mathrm{e}$ & $1,002 \mathrm{e}$ & $\hat{y}=641.6+4.58 x$ & $0.91^{*}$ \\
\hline $20-25$ & $668 \mathrm{f}$ & $735 \mathrm{e}$ & $769 \mathrm{e}$ & $1,036 \mathrm{e}$ & $\hat{y}=641.5+4.58 x$ & $0.94^{*}$ \\
\hline $25-30$ & 802 e & 802 e & $802 \mathrm{e}$ & $1,025 \mathrm{e}$ & $\hat{y}=757.4+2.86 x$ & $0.77^{*}$ \\
\hline $30-35$ & $735 \mathrm{f}$ & $769 \mathrm{e}$ & $780 \mathrm{e}$ & $1,002 \mathrm{e}$ & $\mathrm{ns}$ & \\
\hline $35-40$ & $668 \mathrm{f}$ & $752 \mathrm{e}$ & $758 \mathrm{e}$ & $802 \mathrm{f}$ & ns & \\
\hline $40-50$ & $668 \mathrm{f}$ & $735 \mathrm{e}$ & $735 \mathrm{e}$ & $668 \mathrm{f}$ & ns & \\
\hline $50-60$ & $535 \mathrm{f}$ & $535 \mathrm{e}$ & $635 \mathrm{e}$ & $601 \mathrm{f}$ & ns & \\
\hline \multirow[t]{2}{*}{$\mathrm{CV}(\%)$} & 9.50 & 11.14 & 8.07 & 13.20 & & \\
\hline & \multicolumn{4}{|c|}{ Mineral N, mg kg-1 } & & \\
\hline $0-2$ & $51.06 \mathrm{a}^{(1)}$ & $62.33 \mathrm{a}$ & $69.43 \mathrm{a}$ & $67.64 \mathrm{a}$ & ns & \\
\hline $2-4$ & $55.46 \mathrm{a}$ & $61.83 \mathrm{a}$ & $69.68 \mathrm{a}$ & $66.11 \mathrm{a}$ & ns & \\
\hline $4-6$ & $46.34 \mathrm{a}$ & $62.59 \mathrm{a}$ & $53.39 \mathrm{~b}$ & $61.21 \mathrm{a}$ & ns & \\
\hline $6-8$ & 45.79 a & $56.69 \mathrm{~b}$ & $55.41 \mathrm{~b}$ & $59.30 \mathrm{a}$ & $\mathrm{ns}$ & \\
\hline $8-10$ & $37.29 \mathrm{~b}$ & $49.72 \mathrm{c}$ & $51.47 \mathrm{~b}$ & $54.32 \mathrm{a}$ & ns & \\
\hline $10-12$ & $40.99 \mathrm{~b}$ & $47.71 \mathrm{c}$ & $46.57 \mathrm{~b}$ & $48.57 \mathrm{~b}$ & ns & \\
\hline $12-14$ & $39.18 \mathrm{~b}$ & $44.54 \mathrm{c}$ & $45.84 \mathrm{~b}$ & $43.27 \mathrm{~b}$ & ns & \\
\hline $14-16$ & $34.68 \mathrm{~b}$ & $46.67 \mathrm{c}$ & $46.11 \mathrm{~b}$ & $41.10 \mathrm{~b}$ & $\mathrm{~ns}$ & \\
\hline $16-18$ & $30.40 \mathrm{~b}$ & $44.15 \mathrm{c}$ & $47.14 \mathrm{~b}$ & $37.70 \mathrm{~b}$ & ns & \\
\hline $18-20$ & $32.91 \mathrm{~b}$ & $42.63 \mathrm{c}$ & $41.83 \mathrm{~b}$ & $43.80 \mathrm{~b}$ & ns & \\
\hline CV (\%) & 13.00 & 5.91 & 13.33 & 18.42 & & \\
\hline
\end{tabular}

(1) Means followed by the same letter in a column do not differ by Scott-Knott ( $\alpha=0.05)$; ns and * $=$ not significant and significant at $5 \%$, respectively.

layer, where the increments were 105, 216 and $345 \%$, whereas in the $25-30 \mathrm{~cm}$ layer pig slurry rates of 20 , 40 and $80 \mathrm{~m}^{3} \mathrm{ha}^{-1}$, respectively, induced increments of 12,20 and $65 \%$ (Table 4). According to Dormaar \& Chang (1995), this can be explained by the constant input of high amounts of $\mathrm{P}$ in soil through successive manure applications. Furthermore, the increase in total $\mathrm{P}$ throughout the soil profile is associated with hydrolysis of organic compounds with subsequent adsorption of inorganic $\mathrm{P}$, with the proper organic molecules, to soil colloids (Hountin et al., 1997).

The levels of available $\mathrm{P}$ also showed an increase to the depth of $60 \mathrm{~cm}$ (Table 4). However, the increment of available $\mathrm{P}$ was more expressive than of total $P$, reaching $762,1,466$ and $3,883 \%$, in the layer $0-2 \mathrm{~cm}$, and 19, 188 and $300 \%$, in the $50-60 \mathrm{~cm}$ layer, at pig slurry rates of 20,40 and $80 \mathrm{~m}^{3} \mathrm{ha}^{-1}$, respectively. This may be explained by the high $\mathrm{P}$ amounts applied in manure in the 93 months of the experiment, mainly in the last two growing seasons (Table 2). In an evaluation of the same experiment, Berwanger et al. (2008) found accumulation of available $P$ to a depth of $15 \mathrm{~cm}$, in soil sampled in May 2005 when 14 pig slurry rates had been applied, totaling $1,124.4 \mathrm{~kg} \mathrm{ha}^{-1}$ of $\mathrm{P}$ in $80 \mathrm{~m}^{3} \mathrm{ha}^{-1}$ of pig slurry. On the other hand, soil in this study was collected in January 2008 after 19 slurry rates had been applied, totaling $2,511.2 \mathrm{~kg} \mathrm{ha}^{-1}$ of $\mathrm{P}$ in a rate of $80 \mathrm{~m}^{3} \mathrm{ha}^{-1}$. In other words, in the last five applications, $1,386.8 \mathrm{~kg}$ $\mathrm{ha}^{-1}$ of $\mathrm{P}$ was added in $80 \mathrm{~m}^{3} \mathrm{ha}^{-1}$ of pig slurry, compared to that found by Berwanger et al. (2008). This large amount of $\mathrm{P}$ applied to soil in a short period may have further contributed to saturate the adsorption sites of reactive particles of the top soil 
Table 4. Amounts of total and available phosphorus (P) in layers of a Typic Hapludalf after 19 pig slurry applications

\begin{tabular}{|c|c|c|c|c|c|c|}
\hline \multirow{2}{*}{ Layer } & \multicolumn{4}{|c|}{ Pig slurry rate $\left(\mathrm{m}^{3} \mathrm{ha}^{-1}\right)$} & \multirow{2}{*}{ Equation } & \multirow{2}{*}{$\mathbf{R}^{2}$} \\
\hline & $\mathbf{0}$ & 20 & 40 & 80 & & \\
\hline $\mathrm{cm}$ & \multicolumn{4}{|c|}{ Total $\mathrm{P}, \mathrm{mg} \mathrm{kg}^{-1}$} & & \\
\hline $0-2$ & $328 \mathrm{a}^{(1)}$ & $673 \mathrm{a}$ & $1,037 \mathrm{a}$ & $1,461 \mathrm{a}$ & $\hat{y}=381.09+14,101 x$ & $0.98 *$ \\
\hline $2-4$ & $279 \mathrm{~b}$ & $523 \mathrm{~b}$ & $963 \mathrm{a}$ & $1,288 \mathrm{~b}$ & $\hat{y}=311.61+12,901 x$ & $0.96 *$ \\
\hline $4-6$ & $273 \mathrm{~b}$ & $458 \mathrm{c}$ & $814 \mathrm{~b}$ & $1,161 \mathrm{c}$ & $\hat{y}=277.67+11,400 x$ & $0.98 *$ \\
\hline $6-8$ & $252 \mathrm{~b}$ & $400 \mathrm{~d}$ & $671 \mathrm{c}$ & $1,001 \mathrm{~d}$ & $\hat{y}=245.24+9,590 x$ & $0.99 *$ \\
\hline $8-10$ & $265 \mathrm{~b}$ & $360 \mathrm{~d}$ & $562 \mathrm{~d}$ & $933 \mathrm{~d}$ & $\hat{y}=228.78+8,603 x$ & $0.99 *$ \\
\hline $10-12$ & $259 \mathrm{~b}$ & $293 \mathrm{e}$ & $464 \mathrm{e}$ & $831 \mathrm{e}$ & $\hat{\mathrm{y}}=199.32+7,502 \mathrm{x}$ & $0.97 *$ \\
\hline $12-14$ & $229 \mathrm{c}$ & $285 \mathrm{e}$ & $423 \mathrm{e}$ & $781 \mathrm{e}$ & $\hat{y}=179.86+7,135 x$ & $0.96^{*}$ \\
\hline $14-16$ & $222 \mathrm{c}$ & $260 \mathrm{e}$ & $381 \mathrm{f}$ & $709 \mathrm{f}$ & $\hat{y}=171.65+6,320 x$ & $0.95 *$ \\
\hline $16-18$ & $199 \mathrm{~d}$ & $241 \mathrm{e}$ & $355 \mathrm{f}$ & $592 \mathrm{~g}$ & $\hat{y}=168.21+5,099 x$ & $0.98 *$ \\
\hline $18-20$ & $198 \mathrm{~d}$ & $226 \mathrm{e}$ & $325 \mathrm{f}$ & $486 \mathrm{~h}$ & $\hat{y}=176.98+3,764 x$ & $0.98 *$ \\
\hline $20-25$ & $167 \mathrm{~d}$ & $187 \mathrm{f}$ & $209 \mathrm{~g}$ & $300 \mathrm{i}$ & $\hat{y}=156.70+1,688 x$ & $0.96 *$ \\
\hline $25-30$ & $150 \mathrm{e}$ & $168 \mathrm{f}$ & $180 \mathrm{~g}$ & $248 \mathrm{i}$ & $\hat{y}=143.73+1,220 x$ & $0.96^{*}$ \\
\hline $30-35$ & $135 \mathrm{e}$ & $191 \mathrm{f}$ & $159 \mathrm{~g}$ & $201 \mathrm{j}$ & ns & \\
\hline $35-40$ & $134 \mathrm{e}$ & $158 \mathrm{f}$ & $161 \mathrm{~g}$ & $154 \mathrm{j}$ & ns & \\
\hline $40-50$ & $122 \mathrm{e}$ & $148 \mathrm{f}$ & $154 \mathrm{~g}$ & $138 \mathrm{j}$ & ns & \\
\hline $50-60$ & $129 \mathrm{e}$ & $147 \mathrm{f}$ & $145 \mathrm{~g}$ & $134 \mathrm{j}$ & $\mathrm{ns}$ & \\
\hline \multirow[t]{2}{*}{$\mathrm{CV}(\%)$} & 10.89 & 10.47 & 10.59 & 8.35 & & \\
\hline & \multicolumn{4}{|c|}{ - Available P, mg kg ${ }^{-1}$} & & \\
\hline $0-2$ & $23.0 \mathrm{a}^{(1)}$ & $198.2 \mathrm{a}$ & $360.3 \mathrm{a}$ & $916.0 \mathrm{a}$ & $\hat{y}=-18,003+11,211 x$ & $0.98^{*}$ \\
\hline $2-4$ & $10.7 \mathrm{~b}$ & $171.3 \mathrm{~b}$ & $346.2 \mathrm{a}$ & $867.3 \mathrm{a}$ & $\hat{y}=-29,260+10,804 x$ & $0.98 *$ \\
\hline $4-6$ & $9.3 \mathrm{~b}$ & $120.9 \mathrm{c}$ & $284.5 \mathrm{~b}$ & $762.9 \mathrm{~b}$ & $\hat{y}=-41,757+9,604 x$ & $0.98^{*}$ \\
\hline $6-8$ & $10.0 \mathrm{~b}$ & $71.1 \mathrm{~d}$ & $222.2 \mathrm{c}$ & $627.5 \mathrm{c}$ & $\hat{y}=-46,637+7,981 x$ & $0.96 *$ \\
\hline $8-10$ & $10.8 \mathrm{~b}$ & $48.5 \mathrm{e}$ & $166.5 \mathrm{~d}$ & $596.0 \mathrm{c}$ & $\hat{y}=-60,035+7,586 x$ & $0.93^{*}$ \\
\hline $10-12$ & $10.5 \mathrm{~b}$ & $35.5 \mathrm{f}$ & $132.0 \mathrm{e}$ & $516.6 \mathrm{~d}$ & $\hat{y}=-56,442+6,573 x$ & $0.92 *$ \\
\hline $12-14$ & $7.3 \mathrm{~b}$ & $22.3 \mathrm{~g}$ & $108.1 \mathrm{e}$ & $316.7 \mathrm{e}$ & $\hat{y}=-28,416+4,058 x$ & $0.95 *$ \\
\hline $14-16$ & $7.3 \mathrm{~b}$ & $18.5 \mathrm{~g}$ & $73.8 \mathrm{f}$ & $265.8 \mathrm{e}$ & $\hat{y}=-26,627+3,371 x$ & $0.92 *$ \\
\hline $16-18$ & $6.5 \mathrm{~b}$ & $13.0 \mathrm{~g}$ & $53.5 \mathrm{f}$ & $218.6 \mathrm{f}$ & $\hat{y}=-23,916+2,766 x$ & $0.90 *$ \\
\hline $18-20$ & $6.0 \mathrm{c}$ & $10.3 \mathrm{~h}$ & $45.9 \mathrm{f}$ & $182.9 \mathrm{f}$ & $\hat{y}=-19,683+2,313 x$ & $0.91^{*}$ \\
\hline $20-25$ & $3.8 \mathrm{c}$ & $6.3 \mathrm{~h}$ & $14.5 \mathrm{~g}$ & $129.1 \mathrm{~g}$ & $\hat{y}=-18,107+1,615 x$ & $0.83^{*}$ \\
\hline $25-30$ & $3.1 \mathrm{c}$ & $5.2 \mathrm{~h}$ & $11.8 \mathrm{~g}$ & $52.9 \mathrm{~h}$ & $\hat{y}=-4,289+0.644 x$ & $0.88^{*}$ \\
\hline $30-35$ & $2.5 \mathrm{c}$ & $7.8 \mathrm{~h}$ & $8.0 \mathrm{~g}$ & $34.3 \mathrm{~h}$ & $\hat{y}=-0.659+0.395 x$ & $0.88^{*}$ \\
\hline $35-40$ & $2.9 \mathrm{c}$ & $4.1 \mathrm{~h}$ & $6.3 \mathrm{~g}$ & $14.7 \mathrm{~h}$ & $\hat{y}=1,731+0.151 x$ & $0.94 *$ \\
\hline $40-50$ & $1.9 \mathrm{c}$ & $2.1 \mathrm{~h}$ & $7.5 \mathrm{~g}$ & $10.7 \mathrm{~h}$ & $\hat{y}=1,343+0.121 x$ & $0.91^{*}$ \\
\hline $50-60$ & $1.6 \mathrm{c}$ & $1.9 \mathrm{~h}$ & $4.6 \mathrm{~g}$ & $6.4 \mathrm{~h}$ & $\hat{y}=1,394+0.064 x$ & $0.93 *$ \\
\hline $\mathrm{CV}(\%)$ & 44.52 & 14.02 & 13.75 & 10.84 & & \\
\hline
\end{tabular}

(1) Means followed by the same letter in a column do not differ by Scott-Knott $(\alpha=0.05)$; ns and ${ }^{*}=$ not significant and significant at $5 \%$, respectively.

layers, reducing the $\mathrm{P}$ binding energy, which stimulated the accumulation and transfer of $\mathrm{P}$ to a depth of $60 \mathrm{~cm}$.

Fertilizer and liming recommendation for notillage crops in southern Brazil (States of Rio Grande do Sul and Santa Catarina) is based on soil analysis of the $0-10 \mathrm{~cm}$ layer (CQFSRS/SC, 2004). Levels of available $P$ and clay content in soil are used as criteria for the recommendation of $\mathrm{P}$. In treatments without slurry application, the available $\mathrm{P}$ content was $12.08 \mathrm{mg} \mathrm{kg}^{-1}$ in the $0-10$ $\mathrm{cm}$ layer, which is considered low (levels between 7.1 and $14 \mathrm{mg} \mathrm{kg}^{-1}$ in soil with $\leq 20 \%$ clay). However, after 19 pig slurry applications, at rates of $20 \mathrm{~m}^{3} \mathrm{ha}^{-1}$, the available $\mathrm{P}$ content increased to 122 $\mathrm{mg} \mathrm{kg}^{-1}$ (increase of $853 \%$ ) and was considered very high ( $>42 \mathrm{mg}$ of available $\mathrm{P}$ in soil with $\leq 20 \%$ of 
clay), according to CQFSRS/SC (2004). After manure application of 40 and $80 \mathrm{~m}^{3} \mathrm{ha}^{-1}$, increases of available $\mathrm{P}$ content in the $0-10 \mathrm{~cm}$ layer were even more significant, reaching 275.9 and $753.9 \mathrm{mg} \mathrm{kg}^{-1}$ (increase of 2,056 and 5,791\%), respectively.

Similar results were obtained by Ceretta et al. (2003) in a study of natural pasture treated with pig slurry. These authors tested 28 manure applications in 48 months and found increases in the levels of available $\mathrm{P}$ of 3,943 and $6,710 \%$ for 20 and $40 \mathrm{~m}^{3} \mathrm{ha}^{-1}$ in the $0-10 \mathrm{~cm}$ layer, respectively. The relevance of the results obtained in this study indicates that successive pig slurry applications provide quantities exceeding the recommended with regard to phosphate fertilizer in annual crops and pasture. Thus, the application of high amounts of manure or even of small quantities with high $\mathrm{P}$ concentrations can raise soil $\mathrm{P}$ levels, exceeding those considered optimal for plant growth, and as a consequence, increase the risk of environmental contamination through $\mathrm{P}$ transfer in runoff and leaching to aquifers. Therefore, the use of more suitable criteria to determine pig slurry quantities according to crop requirements, based on the method used by CQFSRS/SC (2004), should be encouraged, considering the need for nutrient application as a complement to the requirement of other nutrients via other sources, especially of commercial mineral fertilizers.

The 19 applications of $0,20,40$ and $80 \mathrm{~m}^{3} \mathrm{ha}^{-1}$ of pig slurry for 93 months did not change the levels of total $\mathrm{K}$ in soil (Table 5). One of the explanations for this result may be the characteristics of the soil, with a low clay content $\left(170 \mathrm{~g} \mathrm{~kg}^{-1}\right)$, high weathering degree and a low amounts of 2:1 clay minerals. This means a low capacity to retain soil $\mathrm{K}$ with higher energy and justifies the fact that the manure application increased available $\mathrm{K}$ in very low percentages to a depth of 60 cm (Table 5).

Similar percentage increases in available K levels in the surface and deeper soil layers indicated a transfer of K in the soil profile, as observed by Scherer et al. (2010) in a Typic Hapludalf with crops treated with annual pig slurry applications for over 20 years. However, in cropping systems where the shoot drymatter is removed from the soil surface, e.g., in the case of some species used in pastures, even with the addition of high amounts of $\mathrm{K}$ fertilizers, the concentrations of available $\mathrm{K}$ in soil may have a negative balance. This was observed by Lloveras et al. (2004) in soils with alfalfa and treated with annual pig slurry applications $\left(0,25\right.$ and $\left.50 \mathrm{~m}^{3} \mathrm{ha}^{-1}\right)$ for two years. Similar results were reported by Ceretta et al. (2003) in Paraíso do Sul, RS, where after 28 pig slurry applications in four years and removal of the pasture every time it was cut, even with manure application rates of up to $40 \mathrm{~m}^{3} \mathrm{ha}^{-1}$, the available $\mathrm{K}$ content was lower than in the area without manuring.
The fertilizer recommendation system adopted in the South of Brazil (CQFSRS/SC, 2004) considers optimal levels of available $\mathrm{K}$ when $>60$ $\mathrm{mg} \mathrm{kg}^{-1}$ in soils with $\mathrm{CEC}_{\mathrm{pH} 7,0}$ between 5 and 15 $\mathrm{cmol}_{\mathrm{c}} \mathrm{dm}^{-3}$. At the beginning of the experiment, available $\mathrm{K}$ in the $0-10 \mathrm{~cm}$ soil layer was $96 \mathrm{mg}$ $\mathrm{kg}^{-1}$, considered high (levels between 60 and 180 $\mathrm{mg} \mathrm{kg}^{-1}$ in soils with $\mathrm{CEC}_{\mathrm{pH} 7,0}$ between 5 and 15 $\mathrm{cmol}_{\mathrm{c}} \mathrm{dm}^{-3}$ ) (CQFSRS/SC, 2004). After 19 pig slurry applications, the levels of available $\mathrm{K}$ were 51,60 , 66 and $86 \mathrm{mg} \mathrm{kg}^{-1}$ in the $0-10 \mathrm{~cm}$ layer, respectively, for $0,20,40$ and $80 \mathrm{~m}^{3} \mathrm{ha}^{-1}$ of pig slurry. There was a small decrease in $\mathrm{K}$ content with slurry application, although quantities of 303 , 606 and $1,212 \mathrm{~kg} \mathrm{ha}^{-1}$ of $\mathrm{K}$ were applied in 20,40 and $80 \mathrm{~m}^{3} \mathrm{ha}^{-1}$ of pig slurry, respectively. These results show that there was $K$ transfer by percolation and transfer of available $\mathrm{K}$ in runoff was also stated by Ceretta et al. (2010). As the shoot dry matter of crops was not withdrawn, the hypothesis of Lloveras et al. (2004) that there is great export of $\mathrm{K}$ through the shoot dry matter of crops could not be considered in this study. However, it was possible to maintain high levels of available $\mathrm{K}$ in the $0-10 \mathrm{~cm}$ layer with successive pig slurry applications, considered ideal by the CQFSRS/SC (2004).

\section{CONCLUSIONS}

The fact that 19 pig slurry applications, over 93 months, did not provide an increase in mineral $\mathrm{N}$ in soil depth, but increased levels of available $\mathrm{P}$ and $\mathrm{K}$, showed that there was transfer of $\mathrm{N}, \mathrm{P}$ and $\mathrm{K}$ to layers below the sampled limit of $60 \mathrm{~cm}$. This shows undesirable environmental and economic consequences of pig slurry application and reinforces the need for a rational use, which involves using lower quantities of manure combined with mineral fertilizers. In this way, it is possible to achieve the objective of applying the required quantity of each nutrient for plant growth, maintaining the desired soil content and especially minimizing the potential risks of environmental contamination by excessive $\mathrm{N}$ and $\mathrm{P}$ applications.

\section{ACKNOWLEDGEMENTS}

The authors are indebted to the National Council for Scientific and Technological Development (CNPq), Brazilian Federal Agency for Support and Evaluation of Graduate Education (CAPES) and the Fundação de Amparo à Pesquisa do Estado do Rio Grande do Sul (FAPERGS) for financial support. 
Table 5. Amounts of total and available potassium (K) in layers of Typic Hapludalf after 19 pig slurry applications

\begin{tabular}{|c|c|c|c|c|c|c|}
\hline \multirow{2}{*}{ Layer } & \multicolumn{4}{|c|}{ Pig slurry rates $\left(\mathrm{m}^{3} \mathrm{ha}^{-1}\right)$} & \multirow{2}{*}{ Regression equation } & \multirow{2}{*}{$\mathbf{R}^{2}$} \\
\hline & $\mathbf{0}$ & 20 & 40 & 80 & & \\
\hline $\mathrm{cm}$ & \multicolumn{4}{|c|}{ Total $\mathrm{K}, \mathrm{mg} \mathrm{kg}^{-1}$} & & \\
\hline $00-2$ & $1,033 \mathrm{~b}^{(1)}$ & $1,073 \mathrm{a}$ & $1,120 \mathrm{a}$ & $1,133 \mathrm{a}$ & $\mathrm{ns}$ & \\
\hline $2-4$ & $1,020 \mathrm{~b}$ & $1,060 \mathrm{a}$ & $1,107 \mathrm{a}$ & $1,133 \mathrm{a}$ & $\mathrm{ns}$ & \\
\hline $4-6$ & $1,000 \mathrm{~b}$ & $1,060 \mathrm{a}$ & $1,107 \mathrm{a}$ & $1,113 \mathrm{a}$ & $\mathrm{ns}$ & \\
\hline $6-8$ & $993 \mathrm{~b}$ & $1,033 \mathrm{~b}$ & $1,053 \mathrm{a}$ & 1,107 a & $\mathrm{ns}$ & \\
\hline $8-10$ & $1,000 \mathrm{~b}$ & $1,020 \mathrm{~b}$ & $1,007 \mathrm{~b}$ & $1,060 \mathrm{~b}$ & $\mathrm{~ns}$ & \\
\hline $10-12$ & $1,000 \mathrm{~b}$ & $1,013 \mathrm{~b}$ & $1,000 \mathrm{~b}$ & $1,060 \mathrm{~b}$ & $\mathrm{~ns}$ & \\
\hline $12-14$ & $987 \mathrm{~b}$ & $1,013 \mathrm{~b}$ & $1,000 \mathrm{~b}$ & $1,060 \mathrm{~b}$ & $\mathrm{~ns}$ & \\
\hline $14-16$ & $993 \mathrm{~b}$ & $1,007 \mathrm{~b}$ & $980 \mathrm{~b}$ & $1,007 \mathrm{~b}$ & $\mathrm{~ns}$ & \\
\hline $16-18$ & $993 \mathrm{~b}$ & $1,007 \mathrm{~b}$ & $993 \mathrm{~b}$ & $1,013 \mathrm{~b}$ & $\mathrm{~ns}$ & \\
\hline $18-20$ & $973 \mathrm{~b}$ & $993 \mathrm{~b}$ & $1,000 \mathrm{~b}$ & $1,013 \mathrm{~b}$ & $\mathrm{~ns}$ & \\
\hline $20-25$ & $980 \mathrm{~b}$ & $993 \mathrm{~b}$ & $1,007 \mathrm{~b}$ & $1,010 \mathrm{~b}$ & $\mathrm{~ns}$ & \\
\hline $25-30$ & $973 \mathrm{~b}$ & $987 \mathrm{~b}$ & $1,013 \mathrm{~b}$ & $1,007 \mathrm{~b}$ & $\mathrm{~ns}$ & \\
\hline $30-35$ & $967 \mathrm{~b}$ & $987 \mathrm{~b}$ & $1,013 \mathrm{~b}$ & $1,013 \mathrm{~b}$ & $\mathrm{~ns}$ & \\
\hline $35-40$ & $1,033 \mathrm{~b}$ & $1,020 \mathrm{~b}$ & $1,020 \mathrm{~b}$ & $1,013 \mathrm{~b}$ & $\mathrm{~ns}$ & \\
\hline $40-50$ & $1,100 \mathrm{a}$ & $1,093 \mathrm{a}$ & $1,067 \mathrm{a}$ & $1,067 \mathrm{~b}$ & $\mathrm{~ns}$ & \\
\hline $50-60$ & $1,127 \mathrm{a}$ & $1,127 \mathrm{a}$ & $1,107 \mathrm{a}$ & $1,153 \mathrm{a}$ & $\mathrm{ns}$ & \\
\hline \multirow[t]{2}{*}{$\mathrm{CV}(\%)$} & 4.02 & 4.75 & 4.69 & 5.90 & & \\
\hline & \multicolumn{4}{|c|}{ - Available $\mathrm{K}, \mathrm{mg} \mathrm{kg}{ }^{-1}$} & & \\
\hline $0-2$ & $113 \mathrm{a}^{(1)}$ & $115 \mathrm{a}$ & 139 a & $150 \mathrm{a}$ & $\hat{y}=111.6+0.507 x$ & $0.90^{*}$ \\
\hline $2-4$ & $56 \mathrm{~b}$ & $74 \mathrm{~b}$ & $68 \mathrm{~b}$ & $86 \mathrm{~b}$ & $\hat{y}=59.6+0.326 x$ & $0.79 *$ \\
\hline $4-6$ & $34 \mathrm{c}$ & $49 \mathrm{c}$ & $59 \mathrm{c}$ & $72 \mathrm{c}$ & $\hat{y}=37.2+0.461 \mathrm{x}$ & $0.96^{*}$ \\
\hline $6-8$ & $28 \mathrm{~d}$ & $34 \mathrm{~d}$ & $38 \mathrm{~d}$ & $61 \mathrm{~d}$ & $\hat{y}=25.7+0.417 x$ & $0.95^{*}$ \\
\hline $8-10$ & $23 \mathrm{e}$ & $27 \mathrm{e}$ & $25 \mathrm{f}$ & $62 \mathrm{~d}$ & $\hat{y}=17.1+0.489 x$ & $0.80^{*}$ \\
\hline $10-12$ & 20 e & $27 \mathrm{e}$ & $22 \mathrm{~g}$ & $45 \mathrm{e}$ & $\hat{y}=18.4+0.289 x$ & $0.77^{*}$ \\
\hline $12-14$ & $25 \mathrm{~d}$ & $37 \mathrm{~d}$ & $31 \mathrm{e}$ & $41 \mathrm{e}$ & $\hat{\mathrm{y}}=27.3+0.171 \mathrm{x}$ & $0.65^{*}$ \\
\hline $14-16$ & $22 \mathrm{e}$ & $32 \mathrm{~d}$ & $27 \mathrm{f}$ & $35 \mathrm{f}$ & $\hat{y}=24.4+0.136 x$ & $0.64^{*}$ \\
\hline $16-18$ & $18 \mathrm{f}$ & $34 \mathrm{~d}$ & $30 \mathrm{~g}$ & $31 \mathrm{f}$ & $\hat{y}=24.1+0.120 x$ & $0.33^{*}$ \\
\hline $18-20$ & $20 \mathrm{e}$ & $28 \mathrm{e}$ & $26 \mathrm{f}$ & $30 \mathrm{f}$ & $\hat{y}=22.4+0.103 x$ & $0.66^{*}$ \\
\hline $20-25$ & $17 \mathrm{f}$ & $21 \mathrm{f}$ & $21 \mathrm{~g}$ & $26 \mathrm{~g}$ & $\hat{y}=17.7+0.103 x$ & $0.97 *$ \\
\hline $25-30$ & $16 \mathrm{f}$ & $22 \mathrm{f}$ & $21 \mathrm{~g}$ & $21 \mathrm{~g}$ & $\hat{\mathrm{y}}=18.4+0.050 \mathrm{x}$ & $0.38^{*}$ \\
\hline $30-35$ & $17 \mathrm{f}$ & $18 \mathrm{f}$ & $19 \mathrm{~g}$ & $24 \mathrm{~g}$ & $\hat{\mathrm{y}}=16.1+0.091 \mathrm{x}$ & $0.94^{*}$ \\
\hline $35-40$ & $15 \mathrm{f}$ & $16 \mathrm{~g}$ & $18 \mathrm{~g}$ & $20 \mathrm{~g}$ & $\hat{y}=15.2+0.061 x$ & $0.98^{*}$ \\
\hline $40-50$ & $15 \mathrm{f}$ & $13 \mathrm{~g}$ & $17 \mathrm{~g}$ & $21 \mathrm{~g}$ & $\hat{y}=13.7+0.080 x$ & $0.76^{*}$ \\
\hline $50-60$ & $13 \mathrm{f}$ & $13 \mathrm{~g}$ & $12 \mathrm{~h}$ & $20 \mathrm{~g}$ & $\hat{y}=11.1+0.093 x$ & $0.71^{*}$ \\
\hline CV (\%) & 7.04 & 6.50 & 7.67 & 8.50 & & \\
\hline
\end{tabular}

${ }^{(1)}$ Means followed by the same letter in a column do not differ by Scott-Knott $(\alpha=0.05)$; ns and ${ }^{*}=$ not significant and significant at $5 \%$, respectively.

\section{LITERATURE CITED}

ADELI, A.; BOLSTER, C.H.; ROWE, D.E.; McLAUGHLIN, M.R. \& BRINK, G.E. Effect of long-term swine effluent application on selected soil properties. Soil Sci., 173:223$235,2008$.

AITA, C.; PORT, O. \& GIACOMINI, S.J. Dinâmica do nitrogênio no solo e produção de fitomassa por plantas de cobertura no outono/inverno com o uso de dejetos de suínos. R. Bras. Ci. Solo. 30:901-910, 2006.
ASSMANN, T.S.; ASSMANN, J.M.; CASSOL, L.C.; DIEHL, R.C.; MANTELI, C. \& MAGIERO, E.C. Desempenho da mistura forrageira de aveia-preta mais azevém e atributos químicos do solo em função da aplicação de esterco líquido de suínos. R. Bras. Ci. Solo, 31:1515-1523, 2007.

ASSOCIAÇÃO BRASILEIRA DA INDÚSTRIA PRODUTORA E EXPORTADORA DE CARNE SUÍNA - ABIPECS. 2009. Disponível em: <http://www.abipecs.org.br>. Acesso em 04 de ago. 2010. 
BALDI, E.; TOSELLI, M.; MARCOLINI, G.; QUARTIERI, M.; CIRILLO, E.; INNOCENTI, A. \& MARANGONI, B. Compost can successfully replace mineral fertilizers in the nutrient management of commercial peach orchard. Soil Use Manage., 26:346-353, 2010.

BASSO, C.J.; CERETTA, C.A.; DURIGON, R.; POLETTO, N. \& GIROTTO, E. Dejeto líquido de suínos: II - perdas de nitrogênio e fósforo por percolação no solo sob plantio direto. Ci. Rural, 35:1305-1312, 2005.

BERGSTRÖM, L. \& KIRCHMANN, H. Leaching and crop uptake of nitrogen and phosphorus from pig slurry as affected by different application rates. J. Environ. Qual., 35:1803-1811, 2006.

BERWANGER, A.L.; CERETTA, C.A. \& RHEINHEIMER, D.S. Alterações no teor de fósforo no solo com aplicação de dejetos líquidos de suínos. R. Bras. Ci. Solo, 32:2525-2532, 2008.

CASSOL, P.C.; GIANELLO, C. \& COSTA, V.E.U. Frações de fósforo em estrumes e sua eficiência como adubo fosfatado. R. Bras. Ci. Solo, 25:635-644, 2001.

CERETTA, C.A.; GIROTTO, E.; LOURENZI, C.R.; TRENTIN, G.; VIEIRA, R.C.B. \& BRUNETTO, G. Nutrient transfer by runoff under no tillage in a soil treated with successive applications of pig slurry. Agric. Ecosyst. Environ., 139:689-699, 2010.

CERETTA, C.A.; BASSO, C.J.; PAVINATO, P.S.; TRENTIN, E.E. \& GIROTTO, E. Produtividade de grãos de milho, produção de matéria seca e acúmulo de nitrogênio, fósforo e potássio na rotação aveia preta/milho/nabo forrageiro com aplicação de dejeto líquido de suínos. Ci. Rural, 35:1287-1295, 2005.

CERETTA, C.A.; DURIGON, R.; BASSO, C.J.; BARCELLOS, L.A.R. \& VIEIRA, F.C.B. Características químicas de solo sob aplicação de esterco líquido de suínos em pastagem natural. Pesq. Agropec. Bras., 38:729-735, 2003.

CHANTIGNY, M.H.; ROCHETTE, P.; ANGERS, D.A.; MASSE, D. \& COTE, D. Ammonia volatilization and selected soil characteristics following application of anaerobically digested pig slurry. Soil Sci. Soc. Am. J., 68:306-312, 2004.

CHANTIGNY, M.H.; ROCHETTE, P. \& ANGERS, D.A. Shortterm $\mathrm{C}$ and $\mathrm{N}$ dynamics in a soil amended with pig slurry and barley straw: A field experiment. Can. J. Soil Sci., 81:131-137, 2001.

COMISSÃO DE QUÍMICA E FERTILIDADE DO SOLO CQFSRS/SC. Manual de adubação e calagem para os estados do Rio Grande do Sul e Santa Catarina. Porto Alegre, 2004.

DAUDÉN, A.; QUÍLEZ, D. \& VERA, M.V. Pig slurry application and irrigation effects on nitrate leaching in Mediterranean soil lysimeters. J. Environ. Qual., 33:2290-2295, 2004.

DAVEREDE, I.C.; KRAVCHENKO, A.N.; HOEFT, R.G.; NAFZIGER, E.D.; BULLOCK, D.G.; WARREN, J.J. \& GONZINI, L.C. Phosphorus runoff from incorporated and surface-applied liquid swine manure and phosphorus fertilizer. J. Environ. Qual., 33:1535-1544, 2004.
DORMAAR, J.F. \& CHANG, C. Effect of 20 annual applications of excess feedlot manure on labile soil phosphorus. Can. J. Soil Sci., 75:507-512, 1995.

HELMKE, P.A. \& SPARKS, D.L. Lithium, sodium, potassium, rubidium, and cesium. In: SPARKS, D.L., ed. Methods of soil analysis: Chemical methods. Madison, 1996. Part 3. p.551-574.

HOUNTIN, J.A.; COUILLARD, D. \& KARAM, A. Soil carbon, nitrogen and phosphorus contents in maize plots after 14 years of pig slurry applications. J. Agr. Sci., 129:187$191,1997$.

JOSHI, J.R.; MONCRIEF, J.F.; SWAN, J.B. \& BURFORD, P.M. Long-term conservation tillage and liquid dairy manure effects on corn. I. Nitrogen availability. Soil Tillage Res., 31:211-224, 1994.

KAMINSKI, J.; BRUNETTO, G.; MOTERLE, D.F. \& RHEINHEIMER, D.S. Depleção de formas de potássio do solo afetada por cultivos sucessivos. R. Bras. Ci. Solo, 31:1003-1010, 2007.

LLOVERAS, J.; ARÁN, M.; VILLAR, P.; BALLESTA, A.; ARCAYA, A.; VILANOVA, X.; DELGADO, I. \& MUNÕZ, F. Effect of swine slurry on alfalfa production and on tissue and soil nutrient concentration. Agron. J., 96:986991, 2004.

LORIA, E.R. \& SAWYER, J.E. Extractable soil phosphorus and inorganic nitrogen following application of raw and anaerobically digested swine manure. Agron. J., 97:879$885,2005$.

LOURENZI, C.R.; CERETTA, C.A.; SILVA, L.S.; TRENTIN, G.; GIROTTO, E.; LORENSINI, F.; TIECHER, T.L. \& BRUNETTO, G. Soil chemical properties related to acidity under successive pig slurry applications. R. Bras. Ci. Solo, 35:1827-1836, 2011.

McDOWELL, R.; SHARPLEY, A. \& FOLMAR, G. Phosphorus export from an agricultural watershed: Linking source and transport mechanisms. J. Environ. Qual., 30:15871595, 2001.

MKHABELA, M.S.; MADANI, A.; GORDON, R.; BURTON, D.; CUDMORE, D.; ELMI, A. \& HART, W. Gaseous and leaching nitrogen losses from no-tillage and conventional tillage systems following surface application of cattle manure. Soil Tillage Res., 98:187-199, 2008.

MURPHY, J. \& RILEY, J.P. A modified single solution method for determination of phosphate in natural waters. Anal. Chem. Acta, 27:31-36, 1962.

SCHERER, E.E.; NESI, C.N. \& MASSOTTI, Z. Atributos químicos do solo influenciados por sucessivas aplicações de dejetos suínos em áreas agrícolas de Santa Catarina. R. Bras. Ci. Solo, 34:1375-1383, 2010.

SCHERER, E.E.; BALDISSERA, I.T. \& NESI, C.N. Propriedades químicas de um Latossolo Vermelho sob plantio direto e adubação com esterco de suínos. R. Bras. Ci. Solo, 31:123-131, 2007.

SIDDIQUE, M.T. \& ROBINSON, J.S. Phosphorus sorption and availability in soils amended with animal manures and sewage sludge. J. Environ. Qual., 32:1114-1121, 2003. 
SMITH, K.A.; JACKSON, D.R. \& PEPPER, T.J. Nutrient losses by surface run-off following the application of organic manures to arable land. 1. Nitrogen. Environ. Pollut., 112:41-51, 2001a.

SMITH, K.A.; JACKSON, D.R. \& PEPPER, T.J. Nutrient losses by surface run-off following the application of organic manures to arable land. 2. Phosphorus. Environ. Pollut., 112:53-60, $2001 b$.

SOIL SURVEY STAFF. Soil taxonomy: a basic system of soil classification for making and interpreting soil surveys. USDA-SCS Agriculture Handbook, v. 436, U.S. Govt. Print. Office, Washington, DC, 1999.
TEDESCO, M.J.; GIANELLO, C.; BISSANI, C.A.; BOHNEN, H. \& VOLKWEISS, S.J. Análises de solo, planta e outros materiais. 2.ed. Porto Alegre, Universidade Federal do Rio Grande do Sul, 1995. 174p.

VADAS, P.A. Distribution of phosphorus in manure slurry and its infiltration after application to soils. J. Environ. Qual., 35:542-547, 2006.

WIENHOLD, B.J. Changes in soil attributes following low phosphorus swine slurry application to no-tillage sorghum. Soil Sci. Soc. Am. J., 69:206-214, 2005. 